
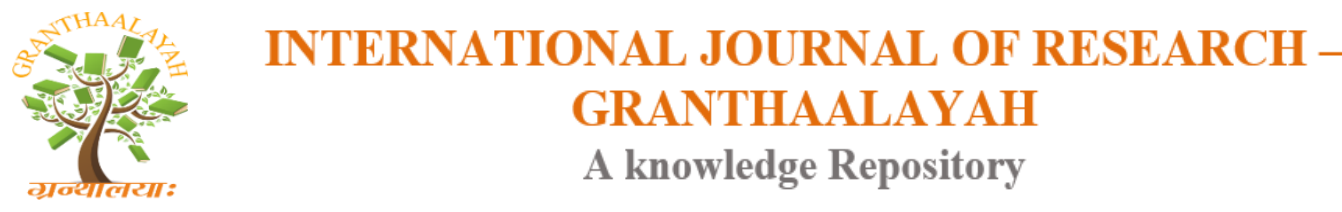

Management

\title{
INVESTMENT CLIMATE AND RELATIVE TECHNICAL EFFICIENCY OF FOOD INDUSTRIES IN NIGERIA
}

\author{
F. A. Ajagbe ${ }^{* 1}$, J. O. Ajetomobi ${ }^{2}$, D. V. Dlamini ${ }^{3}$ \\ ${ }^{* 1}$ Department of Entrepreneurial Studies, College of Management Sciences, Federal University \\ of Agriculture, Abeokuta, Nigeria \\ ${ }^{2,3}$ Department of Agricultural Economics and Management, University of Swaziland, Luyengo, \\ Swaziland
}

\begin{abstract}
This study examined the influence of investment climate on technical efficiencies of industries in Nigeria. The study was conducted in two phases namely (i) an estimation of the technical efficiency (TE) was carried out and, (ii) differences in TE across firms were statistically related to indicators of investment climate and firm-level characteristics. The analyses made use of 2009 World Bank Enterprise survey data on Nigeria. The results showed that food industry was more labour intensive and less efficient than other industries in Nigeria. The importance of scale, export and firm ownership was evident from the significance of the variables in all the industries. The results point to the fact that firms in Nigeria can improve their productivity by learning from customers and by facing international competition. Investment climate difficulties had less effect on food industries than others. The sector could be a good starting point in the nation's industrialization policy drive if available resources can be utilized optimally.
\end{abstract}

Keywords: Investment Climate; Infrastructure; Efficiency; Food Industry; Nigeria.

Cite This Article: F. A. Ajagbe, J. O. Ajetomobi, and D. V. Dlamini. (2018). "INVESTMENT CLIMATE AND RELATIVE TECHNICAL EFFICIENCY OF FOOD INDUSTRIES IN NIGERIA." International Journal of Research - Granthaalayah, 6(1), 284-296. https://doi.org/10.29121/granthaalayah.v6.i1.2018.1616.

\section{Introduction}

In various developing nations, firm-level production, trade, and distribution are undergoing major resource control, land use reform and operation, business model and linkages with buyers and suppliers. This is essential in the reality of the consequences of globalization. At present, globalization and expanding international markets in many developing countries offer opportunities for their producers to compete in emerging national and international markets. In this world of competition, producers from developing nations need to gain optimal control over production, trade and distribution in order to (i) operate in a cost-effective way and (ii) guarantee the quality and value added of their products (Dolan and Humphrey 2004). 
Generally speaking, much of the differences in industrial performance between Africa and other developing countries are linked with the business investment climate and infrastructure in Africa including physical, institutional and regulatory environment for private sector initiatives. In recent time, the cost of doing business in Africa is put at between 20 and $40 \%$ above the value for other developing nations. While improving the investment climate generally for all firms is beneficial, investment climate that is more favourable towards agri-food system than other sectors might be more reasonable for African countries for the following reasons: (i) regional African markets are becoming increasingly important source of demand transformation in technology, production, size of business,

growth for food products, (ii) The continent already possess valuable experience, skills and technical knowhow in agribusiness and (iii) cost of doing agribusiness is relatively low compare to other firms since bulk of the rural population are producers of the primary products.

In Nigeria, industrialization strategy is four pronged. The first element is to achieve significant improvements in the quantum and structure of the primary production base to reduce the cost of input materials required in the secondary sector. The second element, which derives from the first, is the achievement of global competitiveness in the production of specific processed or manufactured goods. Food industry is of particular relevance here due to the existence of primary resource and location advantages. The third element is the stimulation of domestic and foreign trade in value-adding goods and services, and the fourth is to foster strong linkages among all sectors of the economy. The economics performance of food industries in Nigeria can therefore be seen as a process involving the entire economy's output performance, but depend basically on the productivity of the sector. Essential to the overall performance of food industries are two main factors, first, the internal factors such as technology, capital, labour, and marketing strategies. The second factor involves investment climate such as government policy and environment in which the industries operate.

In terms of specific policy intervention, food industry in Nigeria can be said to be enjoying some preferential treatment when compared to others. For instance, the World Bank in 2003 approved credits totaling $\$ 300$ millions to boost the government efforts to expand agricultural sector. More than one third of the credit is allocated to support the government Agricultural Transformation Agenda. The main aim of the Agricultural Transformation Agenda is to contribute to the private sector-led agricultural growth for food security, creation of jobs and shared wealth. Its specific objective is to increase, on a sustainable basis, the income of smallholder farmers and rural entrepreneurs that are engaged in the production, processing, storage and marketing of the priority commodity value chains. To achieve the objective, government set up four staple crop processing zones in 7 states of the federation to service numerous farmers and rural entrepreneur participating in agricultural production and commodity value chain. Given this particular focus on agro-industrial development, this study will attempt to provide evidence of the contribution of the investment climates to the performance of food industries in Nigeria relative to other industries.

Up till now, more works on firm level productivity in Nigeria focuses on primary agricultural commodities and the non-food manufacturing sector than food processing sector. A major research which considered Nigerian food industries alongside other developing nations was 
carried out by Seliola and Seker (2011). The study which covered 2006-2007 classified Nigeria among nations with low average productivity in food, garment and chemical industries. Chete and Adenikinju (2002) investigated the roles of trade policies in fostering productivity growth in Nigerian manufacturing sector between 1962 and 1985. They found positive correlation between trade liberalization and productivity growth. Ajetomobi (2011) included Nigeria in his study of the total factor productivity of selected agricultural commodities in ECOWAS. The study showed a better productivity for the nation's agriculture than when it was included in the estimates of the productivity of agriculture in Africa. Oni et al,. (2009) analyzed the trend and drivers of total factor productivity of Agriculture in Nigeria. The results showed low productivity of large scale agriculture and established farm size as the major driver of increasing agricultural productivity in Nigeria rather than modern technology.

In spite of the relevance of food industries in Nigerian economy and the tendency for the growth given increasing agricultural productivity in the nation, specific attention has not been given to its productivity as observed in some developing nations. For instance, Ahmed (2012) in his study on productivity of food industries in Malaysia, discovered that the factors affecting output growth in Malaysian food industries are capital, labour, and materials, as well as the qualities of these inputs. He reported characteristically low productivity levels for 13 out of 27 food industries over his period of analysis (1971-2000). Rahim et al., (2011) compared the productivity of food industries to those of other industries in Iran between 1971 and 2006. He found out that the productivity of food industries was lower than the average for the all industries in the country. While some of the work reviewed productivity of food industries and the drivers, specific work on the effects of investment climate on the productivity is scanty in developing nations. The closest so far have been Veeramani and Goldar (2004) on India, Escribano and Guasch (2005) on Guatemala, Hondura and Nicaragua as well as Dollar et.al., (2005), Kinda et al (2011) on MENA countries and Bastor (2004) on developing nations as a whole.

Against the above background, the research questions of interest in this study are: (i) what are the productivity levels of food industries in Nigeria and (ii) what is the influence of investment climates on the productivity of food industries in Nigeria relative to others? Hence the following are the research objectives; to

1) Estimate the technical efficiencies of industries in Nigeria

2) Compare the effects of investment climate on the technical efficiency of food industries with those of others

\section{Materials and Methods}

\subsection{Stylized Facts about Food Industries in Nigeria}

Following the ISIC (revision 3.1) classification, the following industries were covered by the 2009 World Bank Investment Climate Survey in Nigeria, namely, all manufacturing sectors, construction, retail and wholesale services, hotels and restaurants, transport, storage, and communications, and computer and related activities. 
Table 1: Types of Industries

\begin{tabular}{|l|l|l|l|l|}
\hline Industry type & Industry & Freq. & Percent & Cum. \\
\hline \multirow{5}{*}{ Manufacturing } & Food & 242 & 7.67 & 7.67 \\
\cline { 2 - 5 } & Garments & 169 & 5.35 & 13.02 \\
\cline { 2 - 5 } & Textiles & 14 & 0.44 & 13.46 \\
\cline { 2 - 5 } & machinery \& equipment & 13 & 0.41 & 13.87 \\
\cline { 2 - 5 } & Chemicals & 30 & 0.95 & 14.82 \\
\cline { 2 - 5 } & Electronics & 2 & 0.06 & 14.89 \\
\cline { 2 - 5 } & non-metallic minerals & 210 & 6.65 & 21.54 \\
\cline { 2 - 5 } & wood, wood products \& furniture & 414 & 13.11 & 34.65 \\
\cline { 2 - 5 } & metal \& metal products & 263 & 8.33 & 42.98 \\
\cline { 2 - 5 } & other manufacturing & 233 & 7.38 & 50.36 \\
\hline Retail & Retail & 643 & 20.37 & 70.73 \\
\hline \multirow{5}{*}{ Rest of the universe } & information technology & 13 & 0.41 & 71.14 \\
\cline { 2 - 5 } & construction \& transport & 133 & 4.21 & 75.36 \\
\cline { 2 - 5 } & hotels \& restaurants & 635 & 20.11 & 95.47 \\
\cline { 2 - 5 } & Other & 143 & 4.53 & 100 \\
\hline & Total & 3,157 & 100 & \\
\hline
\end{tabular}

The manufacturing coverage included the following sub-sector: food and beverages, garments; textiles, machinery and equipment, chemicals, electronics, non-metallic minerals, wood and wood products, metal and metal products and other manufacturing industries. The importance of each industry on three factors; gross output, value added and employees is presented in Table 2. Food and beverage processing sector as a whole is the second largest manufacturing group in Nigeria in terms of gross output, value added and number of employees. It is next in line to metal and metal products and include processing, packaging, domestic distribution, and exports of packaged staples, branded foods products, beverages, and other edibles. Generally, there are large differences in the size of different industries in the enterprise survey. The six largest industries covered more than $75 \%$ of total gross output, value added and the number of employees. They are hotels and restaurants, retails, wood and wood products, metal and metal products, food and beverages and non-metallic minerals. Given the priority accorded food and beverage processing, the industry is expected to be more productive than others but Table 2 shows that it is fifth in the order of importance based on gross output, value added and number of employee.

Table 2: Importance of industries

\begin{tabular}{|l|l|l|l|}
\hline Industry & Gross output & value added & Employee \\
\hline Chemicals & $1.07 \%$ & $1.05 \%$ & $1.01 \%$ \\
\hline Electronics & $0.11 \%$ & $0.12 \%$ & $0.14 \%$ \\
\hline Food & $7.24 \%$ & $7.17 \%$ & $7.31 \%$ \\
\hline Garments & $5.34 \%$ & $5.38 \%$ & $5.28 \%$ \\
\hline Machinery \& equipment & $0.54 \%$ & $0.54 \%$ & $0.52 \%$ \\
\hline Metal and metal products & $9.02 \%$ & $9.04 \%$ & $9.02 \%$ \\
\hline Non - metallic minerals & $7.03 \%$ & $7.13 \%$ & $7.26 \%$ \\
\hline Other manufacturing & $7.24 \%$ & $7.25 \%$ & $7.105 \%$ \\
\hline
\end{tabular}




\begin{tabular}{|l|l|l|l|}
\hline Textiles & $0.54 \%$ & $0.52 \%$ & $0.53 \%$ \\
\hline Wood, wood products and furniture & $12.65 \%$ & $12.71 \%$ & $12.58 \%$ \\
\hline retail & $19.56 \%$ & $19.42 \%$ & $19.34 \%$ \\
\hline Construction and transport & $4.15 \%$ & $4.17 \%$ & $4.23 \%$ \\
\hline Hotels and restaurants & $20.52 \%$ & $20.50 \%$ & $20.58 \%$ \\
\hline Information and technology & $0.37 \%$ & $0.40 \%$ & $0.40 \%$ \\
\hline Others & $4.59 \%$ & $4.63 \%$ & $4.71 \%$ \\
\hline Total & 100.00 & 100.00 & 100.00 \\
\hline
\end{tabular}

\subsection{Empirical Model Specification and Estimation Technique}

In this study Technical Efficiency (TE) was estimated for food, garment, other manufacturing, rest of the world and retail industries. The data were pooled across the 26 cities covered by the 2009/2010 World Bank Enterprise data for Nigeria. Differences and similarities between food and other industries across cities were analyzed. The computational methods are shown in the next section.

\subsection{Firm-level Technical Efficiency}

A Cobb-Douglas production frontier is estimated for food, garment, other, rest of the world (ROW) and retail industries. The estimation of the Firm-level Technical Efficiency is derived from the production frontier estimated with maximum likelihood method. The method permits division of the error term into two independents factors: the error term $(v)$, with a normal distribution, and the Technical Efficiency $(u)$, which follows a truncated normal distribution. The technology of production defines the relationship between the Value Added $(Y)$ as the dependent variable and Capital $(K)$ and Labor $(L)$.as the independent.

$\log \left(Y_{i, j}\right)=a \log \left(K_{i, j}\right)+b \log \left(L_{i, j}\right)+c_{i}-u_{i, j}+v_{i, j}$

$Y_{i, j}:$ Value added (Total sales less total purchased material)

$K_{i, j}:$ Capital

$L_{i, j}$ : Labour (Number of permanent workers in 2008)

$c_{i}$ : city dummy variables

$v_{i, j:}$ Error term

$u_{i, j}$ : Technical efficiency

$i / j:$ Industries and cities

\subsection{Assessment of the effects of investment climate on firm-level productivity}

The second objective of this study is to assess the effects of investment climate variables on the technical efficiencies of the industries. The World Bank Investment Climate (IC) surveys made available information on a large number of investment climate $(I C)$ variables as well as general 
information on firms' status, productivity, sales and supplies. In the questionnaire, the IC variables are classified into 6 broad categories: (a) Infrastructures and Services, $(\boldsymbol{b})$ Finance, (c) Business-Government Relations, (d) Conflict Resolution/Legal Environment, $(\boldsymbol{e})$ Crime, and $(\boldsymbol{f})$ Capacity, Innovation, Learning. The survey contains multiple indicators for different categories. The correlation between the IC indicators was high. One solution applied in some studies and adopted in this study has been to restrict the analysis to a limited number of indicators and accept the omitted variable bias. This however poses the question as to whether the $I C$ variables used provide an overall representative description of the business environment and whether strength of result is due to the particular selection of variables. Based on data availability and results of the correlation analysis, the IC indicators used in the analysis were limited to the following: Average number of days to claim goods from custom (d1b2), Total losses for the year as a \% of annual sales (g1a4), Value of domestic shipment lost in transit due to breakage and spoilage (g7a), informal payment/gifts to given public officials as a \% of total sales (i1c1), Number of days to obtain telephone lines (i2a2), Operating license dummy (Yes = 1, No = 0) (i2f2), Number of times establishment is visited by, inspected by, or required to meet with tax officials? (i3b) and Power interruption (pwint). In the empirical model, same IC representation was assumed for all industries. The empirical model is shown in equation 1

$$
\begin{aligned}
& \log \left(Y_{i, j}\right)=a \log \left(K_{i, j}\right)+b \log \left(L_{i, j}\right)+\operatorname{cons}+c\left(d_{1} b_{2}\right)+d\left(g_{1} a_{4}\right)+e\left(g_{7} a\right)+f\left(i_{1} C_{1}\right)+ \\
& g\left(i_{2} a_{2}\right)+h\left(i_{2} f_{2}\right)+i\left(i_{3} b\right)+j(p w i n t)+k(\operatorname{size})+l(\exp o r t)+m(o w n)+c_{i}+v_{i, j}
\end{aligned}
$$

Where

$Y_{i, j}:$ Value added (Total sales less total purchased material)

$K_{i, j}:$ Capital

$L_{i, j}:$ Labour (Number of permanent workers in 2008)

$c_{i}$ : city dummy variables

$d_{1} b_{2}:$ Average number of days to claim goods from custom

$g_{1} a_{4}$ : Total losses for the year as a $\%$ of annual sales

$g_{7} a$ : Value of domestic shipment lost in transit due to breakage and spoilage

$i_{1} c_{1}$ : informal payment/gifts to given public officials as a $\%$ of total sales

$i_{2} a_{2}$ : Number of days to obtain telephone lines

$i_{2} f_{2}$ : Operating license dummy (Yes $=1$, No $=0$ )

$i_{3} b$ : Number of times establishment is visited by, inspected by, or required to meet with tax officials?

Pwint: Power interruption: Total duration of power outages suffered by the plant in hours (equals average duration times the total number of power outages

Size: Ranking: Small $=1$, Medium $=2$ and Large $=3$

Export: Percentage of establishment's sales scheduled for direct exports

Ownership: Percentage of this firm owned by largest shareholder(s) 
Following Kinda et al 2011, all the coefficients were estimated by using one step procedure. In other words, the production frontiers and the factors contributing to firms' Technical Efficiency (TE) were estimated at the same time. This is to address the problem of possible correlation between the firm-level productivity (TE) and production function inputs. In order to solve the problem of endogeneity of some of the inputs, all the investment climate variables are measured as city-sector averages of the firm-level observations (Dollar et al 2004, Kinda et al 2011).

\section{Results and Discussions}

\subsection{Overview of the Dataset}

Table 3 shows the descriptive statistics of the output measured in Naira. On the average, food industries recorded the highest sales. At present the sector is contributing more to economic growth in the country than other industries. Labour was measures as the number of employee in 2008. Food industries had the highest employer of labour on the average followed by other manufacturing industries. Retail industries were the smallest employer of labour in the country. Invariably, the costs of production (labour, materials and capital) are higher in food industries that other sectors.

Table 3: Production data by industries

\begin{tabular}{|c|c|c|c|c|c|c|}
\hline Industry & Sales & Employees & Labor cost & Material cost & Capital & Statistic \\
\hline \multirow[t]{3}{*}{ Food } & 243 & 243 & 243 & 243 & 233 & No of obs \\
\hline & $5.09 \mathrm{E}+08$ & 70.1358 & $3.59 \mathrm{E}+07$ & $2.95 \mathrm{E}+08$ & $9.65 \mathrm{E}+07$ & Mean \\
\hline & $1.96 \mathrm{E}+07$ & 318.8438 & $2.08 \mathrm{E}+08$ & $1.88 \mathrm{E}+09$ & $4.16 \mathrm{E}+08$ & S.D \\
\hline \multirow[t]{3}{*}{ Garment } & 168 & 168 & 168 & 168 & 160 & No of obs \\
\hline & $1.01 \mathrm{E}+07$ & 12.78571 & 2417713 & 4146900 & 2078071 & Mean \\
\hline & 140085.3 & 11.59865 & 3810047 & $1.12 \mathrm{E}+07$ & 3366871 & S.D \\
\hline \multirow[t]{3}{*}{ other $\mathrm{mfg}$} & 1181 & 1181 & 1181 & 1179 & 1156 & No of obs \\
\hline & $8.92 \mathrm{E}+07$ & 19.24725 & 7580855 & $4.67 \mathrm{E}+07$ & $9.07 \mathrm{E}+07$ & Mean \\
\hline & 5069145 & 31.86241 & $3.76 \mathrm{E}+07$ & $4.33 \mathrm{E}+08$ & $2.20 \mathrm{E}+09$ & S.D \\
\hline \multirow[t]{3}{*}{ Retail } & 642 & 642 & 642 & 642 & 0 & No of obs \\
\hline & $3.64 \mathrm{E}+07$ & 10.64019 & 2148777 & $1.90 \mathrm{E}+07$ & . & Mean \\
\hline & 1283083 & 14.03839 & 9322471 & $8.65 \mathrm{E}+07$ & . & S.D \\
\hline \multirow{3}{*}{$\begin{array}{l}\text { rest of the } \\
\text { universe }\end{array}$} & 923 & 923 & 923 & 38 & 0 & No of obs \\
\hline & $1.06 \mathrm{E}+08$ & 26.6273 & 7222713 & $1.72 \mathrm{E}+07$ & . & Mean \\
\hline & 6472974 & 60.82962 & $2.41 \mathrm{E}+07$ & $6.85 \mathrm{E}+07$ & . & S.D \\
\hline \multirow[t]{3}{*}{ Total } & 3157 & 3157 & 3157 & 2270 & 1549 & No of obs \\
\hline & $1.11 \mathrm{E}+08$ & 23.22775 & 8275387 & $6.18 \mathrm{E}+07$ & $8.24 \mathrm{E}+07$ & Mean \\
\hline & 7232809 & 97.56952 & $6.41 \mathrm{E}+07$ & $6.94 \mathrm{E}+08$ & $1.90 \mathrm{E}+09$ & S.D \\
\hline
\end{tabular}


The frequency distribution of the most serious IC problems by city and industrial stratification are presented in Appendix B. Selection of IC variables depend on the degree of missing variables after computing the city-sector averages. The tables show that enough variation exist across the city to use city-sector averages to control for endogeneity problem.

\subsection{Firm-Level Technical Efficiency}

A production frontier was estimated for each industry. The essence is to have a homogeneous production frontier which makes it easier to attribute the residual to differences in efficiency. The choice is justified by differences in coefficients of capital and labor in Table 4.

Table 4: Estimates of the Stochastic Production Frontier

\begin{tabular}{|l|l|l|l|l|l|}
\hline & Food & Garment & Other & Row & Retail \\
\hline Frontier Log (labor) & $\begin{array}{l}0.516^{* *} \\
(0.000)\end{array}$ & $\begin{array}{l}0.570^{* *} \\
(0.046)\end{array}$ & $\begin{array}{l}0.529^{* *} \\
(0.000)\end{array}$ & $\begin{array}{l}0.522^{* *} \\
(0.000)\end{array}$ & $\begin{array}{l}0.525^{* *} \\
(0.000)\end{array}$ \\
\hline Log (capital) & $\begin{array}{l}0.243^{* *} \\
(0.000)\end{array}$ & $\begin{array}{l}0.194^{* *} \\
(0.017)\end{array}$ & $\begin{array}{l}0.243^{* *} \\
(0.000)\end{array}$ & $\begin{array}{l}0.243^{* *} \\
(0.000)\end{array}$ & $\begin{array}{l}0.240^{* *} \\
(0.000)\end{array}$ \\
\hline constant & $\begin{array}{l}11.458^{* *} \\
(0.000)\end{array}$ & $\begin{array}{l}11.962^{* *} \\
(0.262)\end{array}$ & $\begin{array}{l}11.430^{* *} \\
(0.000)\end{array}$ & $\begin{array}{l}11.445^{* *} \\
(0.000)\end{array}$ & $\begin{array}{l}11.438^{* *} \\
(0.000)\end{array}$ \\
\hline Mu & $0.255^{* *}$ & $0.0029^{*}$ & $0.2403^{* *}$ & $0.2455^{* *}$ & $0.2306^{* *}$ \\
constant & $(0.046)$ & $(0.404)$ & $(0.022)$ & $(0.024)$ & $(0.031)$ \\
\hline Usigma & -2.326 & -2.313 & $-2.315^{* *}$ & $-2.336^{* *}$ & $-2.281^{* *}$ \\
constant & $(0.185)$ & $(0.727)$ & $(0.087)$ & $(0.097)$ & $(0.119)$ \\
\hline Vsigma constant & -37.924 & -4.263 & -36.435 & -36.877 & -36.519 \\
& $(729.516)$ & $(0.581)$ & $(-226.669$ & $(288.118)$ & $(306.960)$ \\
\hline Likelihood ratio & 25.912 & 15.629 & 136.790 & 108.280 & 74.685 \\
\hline Sigma_u & 0.312 & 0.315 & 0.314 & 0.311 & 0.320 \\
\hline Sigma_v & 0.000 & 0.119 & 0.000 & 0.000 & 0.000 \\
\hline Sigma_u/usigma & 0.134 & 0.136 & 0.136 & 0.133 & 0.140 \\
\hline N & 210 & 143 & 1005 & 784 & 555 \\
\hline
\end{tabular}

Note: $* *$ indicates significance at $1 \%$ probability level

In all the industries, the sum of the coefficients relative to labor and capital inputs was about 0.75 and their coefficients were strongly statistically significant at the $1 \%$ level of significance. Table 4 also specifies the percentage of the residual explained by the Technical Efficiency (TE). In all industries, the efficiency term accounted for a significant part of the total residuals and was statistically significant at I\% significant level. This justifies the production frontier approach, against the production function approach. In this model, $T E$ varied between $13.4 \%$ and $14 \%$ of the error term in all the industries.

In Table 5, technical efficiencies were also expressed in percentage of the average for food industry. The results indicate that other manufacturing industries had the highest level of technical efficiency followed by retail on the average. Technical efficiency in food industry was lower than those of other industries apart from garment. 
Table 5: Firm-Level Technical Efficiency

\begin{tabular}{|c|c|c|c|c|c|c|c|c|c|c|}
\hline City & food & garment & other & Row & Retail & food & garment & Other & row & retail \\
\hline Abakaliki & 0.37 & 0.27 & 0.37 & 0.37 & 0.37 & 100 & 74.17 & 100.38 & 100.17 & 100.26 \\
\hline Ado-Ekiti & 0.35 & 0.26 & 0.36 & 0.35 & 0.36 & 100 & 73.3 & 100.34 & 100.15 & 100.23 \\
\hline Akure & 0.35 & 0.26 & 0.35 & 0.35 & 0.35 & 100 & 73.4 & 100.34 & 100.15 & 100.23 \\
\hline Asaba & 0.37 & 0.27 & 0.37 & 0.37 & 0.37 & 100 & 73.87 & 100.44 & 100.2 & 100.31 \\
\hline Benin City & 0.36 & 0.27 & 0.36 & 0.36 & 0.36 & 100 & 74.47 & 100.54 & 100.25 & 100.37 \\
\hline $\begin{array}{l}\text { Birnin } \\
\text { Kebbi }\end{array}$ & 0.35 & 0.26 & 0.35 & 0.35 & 0.35 & 100 & 73.38 & 100.46 & 100.21 & 100.32 \\
\hline Damaturu & 0.34 & 0.25 & 0.34 & 0.34 & 0.34 & 100 & 72.9 & 100.55 & 100.25 & 100.38 \\
\hline Dutse & 0.35 & 0.25 & 0.35 & 0.35 & 0.35 & 100 & 73.09 & 100.5 & 100.23 & 100.35 \\
\hline Gombe & 0.35 & 0.26 & 0.36 & 0.35 & 0.36 & 100 & 73.54 & 100.54 & 100.25 & 100.38 \\
\hline Gusau & 0.36 & 0.27 & 0.37 & 0.37 & 0.37 & 100 & 73.54 & 100.38 & 100.17 & 100.26 \\
\hline Ibadan & 0.36 & 0.26 & 0.36 & 0.36 & 0.36 & 100 & 74.23 & 100.46 & 100.21 & 100.32 \\
\hline Ilorin & 0.35 & 0.26 & 0.35 & 0.35 & 0.35 & 100 & 73.09 & 100.34 & 100.15 & 100.23 \\
\hline Jalingo & 0.37 & 0.28 & 0.37 & 0.37 & 0.37 & 100 & 74.67 & 100.38 & 100.17 & 100.26 \\
\hline Jos & 0.35 & 0.25 & 0.35 & 0.35 & 0.35 & 100 & 73.14 & 100.45 & 100.21 & 100.31 \\
\hline Katsina & 0.38 & 0.28 & 0.38 & 0.38 & 0.38 & 100 & 73.89 & 100.34 & 100.16 & 100.24 \\
\hline Lafia & 0.36 & 0.27 & 0.37 & 0.36 & 0.37 & 100 & 74.88 & 100.45 & 100.21 & 100.31 \\
\hline Lokoja & 0.37 & 0.27 & 0.37 & 0.37 & 0.37 & 100 & 74.43 & 100.62 & 100.28 & 100.43 \\
\hline Maiduguri & 0.34 & 0.25 & 0.34 & 0.34 & 0.34 & 100 & 72.88 & 100.5 & 100.23 & 100.35 \\
\hline Makurdi & 0.37 & 0.27 & 0.37 & 0.37 & 0.37 & 100 & 74.47 & 100.49 & 100.22 & 100.34 \\
\hline Minna & 0.36 & 0.27 & 0.37 & 0.36 & 0.36 & 100 & 73.48 & 100.48 & 100.22 & 100.33 \\
\hline Osogbo & 0.37 & 0.27 & 0.37 & 0.37 & 0.37 & 100 & 73.74 & 100.47 & 100.22 & 100.33 \\
\hline Owerri & 0.37 & 0.28 & 0.38 & 0.38 & 0.38 & 100 & 74.72 & 100.36 & 100.16 & 100.25 \\
\hline $\begin{array}{l}\text { Port- } \\
\text { Harcourt }\end{array}$ & 0.37 & 0.28 & 0.38 & 0.37 & 0.37 & 100 & 73.95 & 100.38 & 100.18 & 100.27 \\
\hline Uyo & 0.36 & 0.26 & 0.36 & 0.36 & 0.36 & 100 & 74.35 & 100.44 & 100.2 & 100.31 \\
\hline Yanagoa & 0.37 & 0.28 & 0.38 & 0.37 & 0.37 & 100 & 73.89 & 100.36 & 100.16 & 100.25 \\
\hline Yola & 0.35 & 0.26 & 0.35 & 0.35 & 0.35 & 100 & 73.19 & 100.44 & 100.2 & 100.31 \\
\hline Total & 0.36 & 0.27 & 0.36 & 0.36 & 0.36 & 100 & 73.79 & 100.44 & 100.20 & 100.31 \\
\hline
\end{tabular}

Source: Authors' Calculation

\subsection{Stochastic Frontier Model with IC variables}

The results of the stochastic production frontier with IC variables across various industries are shown in Table 6, the model is estimated at the sector level and the sample size varies from 234 observations in food 166 in garment, 586 in retail, 776 in the rest of the universe to 1135 observations in other manufacturing industries. The production frontier was estimated with Cobb-Douglass production function. An advantage of the model is that the coefficient of labour and capital expressed in logarithmic form can be treated as the variable's direct elasticity. The results show that the elasticites of capital and labor are different from one industry to another. Similar to the non-parametric estimates, the coefficients of labour and capital are strongly significant. This indicates the robustness of the model. The coefficient of labour is higher than that of capital in all the industries. This implies that all the industries in Nigeria are labour intensive. There is a dire need to improve capital technologies in all sectors. Apart from garment, the coefficient of labour for food 
industry is higher than in other sectors. In essence, food industries in Nigeria can be said to be more labour intensive than other industries. The estimations also indicate that quite significant differences in production frontiers can be explained by city-specific conditions. This hypothesis is supported by the data, as several city dummies are significant. Nevertheless some city dummies are omitted because of multicollinearity problems.

In respect of the effects of investment climates, the results clearly shows that differences in firmlevel efficiencies across industries in Nigeria can be attributed to discrepancies in investment climate. The results confirm that power interruption is critical to development of industries in Nigeria. Surprisingly the variable is insignificant in the food model. This might be due to small scale nature of most food firms in Nigeria. Another interesting aspect of the results is that most of the investment climate variables influence productivity of other manufacturing industries positively while they remain insignificant in respect of food. This might be a good reason for relatively low performance of food industry. According to Clemens and Reiner, 2009, poor finance, inadequate modern technologies, information asymmetric, government bureaucratic bottlenecks, power interruption and corruption need to be given adequate attention in order to address problems of poor returns and high production costs in food industries.

The importance of scale, export and firm ownership is evident from the significance of the variables in all the industries. The results point to the fact that firms in Nigeria can improve their productivity by learning from customers and by facing international competition. Likewise, foreign ownership may increase productivity if foreign investors transfer new technologies and management techniques.

Table 6: Estimates of the Stochastic Production Frontier with Individual IC Variables

\begin{tabular}{|c|c|c|c|c|c|c|}
\hline Variable & Food & garment & Other & Row & Retail & pool \\
\hline \multirow[t]{2}{*}{$\mathrm{Ll}$} & $0.793^{* * *}$ & $0.817^{* * *}$ & $0.766^{* * *}$ & $0.757^{* * *}$ & $0.774^{* * *}$ & $0.780^{* * *}$ \\
\hline & $(8.458)$ & (10.618) & $(25.609)$ & $(22.393)$ & $(11.355)$ & (39.964) \\
\hline \multirow[t]{2}{*}{$\mathrm{Lc}$} & $0.321^{* * *}$ & $0.137^{* * *}$ & $0.176^{* * *}$ & $0.192^{* * *}$ & $0.338^{* * *}$ & $0.20^{* * * *} 1$ \\
\hline & $(7.860)$ & $(3.282)$ & $(12.765)$ & $(14.749)$ & $(11.605)$ & $(29.687)$ \\
\hline \multirow[t]{2}{*}{$\mathrm{d} 1 \mathrm{~b} 2$} & 0.005 & 0.049 & $0.079^{* * *}$ & 0.018 & $0.048^{* *}$ & $0.01^{*} 1$ \\
\hline & $(0.060)$ & $(0.993)$ & $(4.322)$ & $(0.970)$ & $(2.021)$ & $(1.651)$ \\
\hline \multirow[t]{2}{*}{ g1a4 } & 0.071 & 0.053 & $-0.053^{*}$ & $0.073^{* *}$ & 0.025 & $0.045^{* *}$ \\
\hline & $(0.457)$ & $(0.871)$ & $(-1.735)$ & $(2.146)$ & $(0.493)$ & $(2.889)$ \\
\hline \multirow[t]{2}{*}{ g7a } & 0.093 & 0.150 & $0.271^{* * *}$ & $0.126^{* *}$ & 0.154 & $0.140^{* * * *}$ \\
\hline & $(0.494)$ & (1.163) & $(4.947)$ & (2.116) & $(1.286)$ & $(4.020)$ \\
\hline \multirow[t]{2}{*}{ i1c1 } & -0.004 & 0.112 & $0.307^{* * *}$ & $0.106^{*}$ & $0.139^{* *}$ & $0.084^{* * *}$ \\
\hline & $(-0.025)$ & $(0.839)$ & $(5.138)$ & $(1.586)$ & $(1.971)$ & $(5.752)$ \\
\hline \multirow[t]{2}{*}{$\mathrm{i} 2 \mathrm{a} 2$} & 0.000 & 0.025 & $0.066^{* * * *}$ & -0.002 & -0.003 & $0.010^{* * * *}$ \\
\hline & $(-0.006)$ & $(1.247)$ & $(8.229)$ & $(-0.331)$ & $(-0.404)$ & $(4.014)$ \\
\hline \multirow[t]{2}{*}{ i2f 2} & -0.014 & 0.003 & $-0.044^{* * * *}$ & 0.030 & 0.027 & -0.002 \\
\hline & $(-0.246)$ & $(0.124)$ & $(-5.407)$ & $(1.274)$ & $(1.181)$ & $(-0.312)$ \\
\hline \multirow[t]{2}{*}{$\mathrm{i} 3 \mathrm{~b}$} & 0.020 & -0.212 & -0.066 & -0.022 & -0.019 & -0.003 \\
\hline & $(0.035)$ & $(-0.863)$ & $(-0.777)$ & $(-0.265)$ & $(-0.117)$ & $(-0.045)$ \\
\hline
\end{tabular}




\begin{tabular}{|l|l|l|l|l|l|l|}
\hline Pwint & 0.0002 & $0.0004^{*}$ & $0.0003^{*}$ & $0.0002^{* *}$ & $0.0003^{*}$ & $0.0003^{*}$ \\
\hline & $(0.025)$ & $(1.604)$ & $(1.609)$ & $(2.248)$ & $(1.599)$ & $(1.718)$ \\
\hline Sizes & 0.068 & $0.151^{*}$ & $0.061^{* *}$ & $0.096^{* *}$ & $0.400^{* * *}$ & $0.067^{* * *}$ \\
\hline & $(0.798)$ & $(1.789)$ & $(1.942)$ & $(2.558)$ & $(4.600)$ & $(3.317)$ \\
\hline Exp & $2.800^{* * *}$ & $2.771^{* * *}$ & $1.736^{* * *}$ & $2.830^{* * *}$ & $1.824^{* * *}$ & $2.533^{* * * *}$ \\
\hline & $(6.979)$ & $(2.759)$ & $(3.982)$ & $(18.300)$ & $(5.010)$ & $(44.286)$ \\
\hline Own & $0.998^{* * *}$ & $0.906^{* * *}$ & $1.420^{* * *}$ & $1.281^{* * *}$ & $1.173^{* * *}$ & $1.309^{* * *}$ \\
\hline & $(3.380)$ & $(3.042)$ & $(3.187)$ & $(7.100)$ & $(4.908)$ & $(20.652)$ \\
\hline Ll & -217.216 & -69.326 & -612.289 & -451.619 & -613.642 & -1979.915 \\
\hline sigma_u & 0.462 & 0.584 & 0.425 & 0.674 & 0.713 & 0.762 \\
\hline sigma_v & 0.627 & 0.350 & 0.379 & 0.422 & 0.716 & 0.476 \\
\hline Wald & & & & & & \\
\hline chi2 & $66031.150^{* * *}$ & $233.274^{* * *}$ & $2473800.600^{* * *}$ & $363975.490^{* * *}$ & $88904.865^{* * *}$ & $551713.910^{* * *}$ \\
\hline N & 234.000 & 166.000 & 1135.000 & 776.000 & 586.000 & 2897.000 \\
\hline
\end{tabular}

The results section should provide details of all of the experiments that are required to support the conclusions of the paper. The section may be divided into subsections, each with a concise subheading.

It is advised that this section be written in past tense. It is a good idea to rely on charts, graphs, and tables to present the information. This way, the author is not tempted to discuss any conclusions derived from the study. The charts, graphs, and table should be clearly labeled and should include captions that outline the results without drawing any conclusions. A description of statistical tests as it relates to the results should be included.

\section{Conclusions and Recommendations}

This study examines the influence of investment climate on the total factor productivity (TFP) of food industries in Nigeria relative to other ones. The study is conducted in two phases namely (i) an estimation of the firm-level productivity is carried out and, (ii) differences in TFP across firms are statistically related to indicators of investment climate, taking into consideration firms characteristics. The analyses use of most recent World Bank Enterprise survey data on Nigeria. In the first phase, three measures of firm-level productivity are explored, namely, labour productivity, total factor productivity and technical efficiency. The results show that productivity of food industries differ significantly from others in most cities in Nigeria. In terms of firm level efficiency, food industries are less efficient than others in all cities. The empirical results also indicate that investment climate matters to productive performance of all industries in Nigeria. An implication of this study is that much effort from policy makers may be needed to build up a conducive investment climate in order to improve performance of food industries relative to others.

\section{Acknowledgements}

People who contributed to the work but do not fit criteria for authorship should be listed in the Acknowledgments, along with their contributions. It is advised that authors ensure that anyone 
named in the acknowledgments agrees to being so named. Funding sources that have supported the work should also be cited.

\section{Appendices}

Appendix B: Most serious IC and infrastructure problems by industries

\begin{tabular}{|c|c|c|c|c|c|c|}
\hline Most serious IC & Food & Garment & $\begin{array}{c}\text { Other } \\
\text { manufacturing }\end{array}$ & Retail & $\begin{array}{c}\text { Rest of the } \\
\text { universe }\end{array}$ & Total \\
\hline Telecommunications & $2(0.8)$ & $2(1.2)$ & $11(0.9)$ & $12(1.9)$ & $6(0.7)$ & $33(1.0)$ \\
\hline Electricity & $152(62.6)$ & $90(53.6)$ & $639(54.1)$ & $292(45.6)$ & $497(53.8)$ & $1,670(52.9)$ \\
\hline Transportation & $13(5.3)$ & $1(0.6)$ & $80(6.8)$ & $44(6.9)$ & $34(3.7)$ & $172(5.4)$ \\
\hline access to land & $5(2.1)$ & $5(3.0)$ & $36(3.0)$ & $22(3.4)$ & $28(3.0)$ & $96(3.0)$ \\
\hline tax rates & $5(2.1)$ & $3(1.8)$ & $62(5.2)$ & $12(1.9)$ & $26(2.8)$ & $108(3.4)$ \\
\hline tax administration & $6(2.6)$ & $1(0.6)$ & $27(2.3)$ & $37(5.8)$ & $31(3.4)$ & $102(3.2)$ \\
\hline $\begin{array}{l}\text { customs and trade } \\
\text { regulations }\end{array}$ & $0(0.0)$ & $0(0.0)$ & $2(0.2)$ & $4(0.6)$ & $6(0.7)$ & $12(0.4)$ \\
\hline Courts & $0(0.0)$ & $0(0.0)$ & $0(0.0)$ & $0(0.0)$ & $3(0.3)$ & $3(0.1)$ \\
\hline labor regulations & $1(0.4)$ & $0(0.0)$ & $2(0.2)$ & $0(0.0)$ & $24(2.6)$ & $27(0.9)$ \\
\hline $\begin{array}{l}\text { inadequately } \\
\text { educated }\end{array}$ & $2(0.8)$ & $1(0.6)$ & $6(0.5)$ & $6(0.9)$ & $7(0.8)$ & $22(0.7)$ \\
\hline business licensing & $1(0.4)$ & $0(0.0)$ & $2(0.2)$ & $6(0.9)$ & $5(0,5)$ & $14(0.4)$ \\
\hline Political enviroment & $1(0.4)$ & $0(0.0)$ & $10(0.8)$ & $7(1.1)$ & $23(2.5)$ & $41(1.3)$ \\
\hline $\begin{array}{l}\text { macroeconomic } \\
\text { environment }\end{array}$ & $5(2.1)$ & $3(1.8)$ & $21(1.8)$ & $23(3.6)$ & $19(2.1)$ & $71(2.2)$ \\
\hline Corruption & $5(2.1)$ & $3(1.8)$ & $21(1.8)$ & $25(3.9)$ & $30(3.3)$ & $84(2.7)$ \\
\hline $\begin{array}{l}\text { crime, theft and } \\
\text { disorder }\end{array}$ & $3(1.2)$ & $0(0.0)$ & $11(0.9)$ & $13(2.0)$ & $16(1.7)$ & $43(1.4)$ \\
\hline $\begin{array}{lr}\text { practices of } & \text { some } \\
\text { informal } & \text { sector } \\
\text { competitors } & \\
\end{array}$ & $4(1.6)$ & $7(4.2)$ & $10(0.8)$ & $8(1.2)$ & $12(1.3)$ & $41(1.3)$ \\
\hline Other & $0(0.0)$ & $0(0.0)$ & $4(0.3)$ & $0(0.0)$ & $2(0.2)$ & $6(0.2)$ \\
\hline policy uncertainty & $3(1.2)$ & $4(2.4)$ & $16(1.6)$ & $9(1.4)$ & $9(1.0)$ & $41(1.3)$ \\
\hline access to finance & $30(12.3)$ & $41(24.4)$ & $206(17.4)$ & $93(14.5)$ & $120(13.0)$ & $490(15.5)$ \\
\hline cost of finance & $5(2.1)$ & $7(4.2)$ & $15(1.3)$ & $27(4.2)$ & $25(2.7)$ & $79(2.5)$ \\
\hline Total & $243(100)$ & $168(100)$ & $1,181(100)$ & $641(100)$ & $923(100)$ & $3,156(100)$ \\
\hline
\end{tabular}

\section{References}

[1] Ahmed E. M. (2012). Malaysia's Food Manufacturing Industries Productivity Determinants. Modern Economy 3:444-453

[2] Ajetomobi, J. O. (2011). Total Factor Productivity of Agricultural Commodities in the Economic Community of West Africa States: 1961-2005. AERC Research Paper 241.

[3] Bastor, F., Nasir, J. (2004) Productivity and Investment Climate; What Matters Most? World Bank Policy Research Paper 3335.

[4] Chete L. N and Adenikinju, A. F (2002). Productivity Growth in Nigerian Manufacturing and its Correlation to Trade Policy Regimes/Indexes (1962-1985). AERC Research Paper 127 
[5] Dolan, Catherine and John Humphrey. (2004). "Changing Governance Patterns in the Trade in Fresh Vegetables between Africa and the United Kingdom." Environment and Planning, 36: 491509.

[6] Dollar, D., Hallward-Dreimeier, M and Mengistae, T. ( 2005). Investment Climate and Firm Performance in Developing Countries. Economic Development and Cultural Change 54(1):1-31.

[7] Escribano, A, and Luis G. J. (2005). Assessing the Impact of the Investment Climate on Productivity Using Firm-Level Data: Methodology and the Cases of Guatemala, Honduras and Nicaragua. World Bank Policy Research Working Paper 3621.

[8] Kinda, T., Plane, P. and Varondakis, M.V.,(2011): Firm Productivity and Investment Climate in Developing Countries. How does Middle and North African Manufacturing Perform? CERDI, Etudes et Documents,26.

[9] Oni, O., E. Nkonya, J. Pender and D. Phillip (2009). Trends and Drivers of Agricultural Productivity in Nigeria. International Food Policy Research Institute, Washington, D.C.

[10] Nordhaus, W.D. and E.D. Kokkelenberg (1999), Nature's Numbers: Expanding the National Economic Accounts to Include the Environment, Washington D.C.: National Academy Press

[11] Raa, T., P. Mohnen, (2002). Neoclassical Growth Accounting and Frontier Analysis: A Synthesis, Journal of Productivity Analysis, 18 (2), 111-128.

[12] Ssliola, F and M. Seker (2011). Total Factor Productivity Across the Developing World. Enterprise Note Series 2011.

[13] Veeramani, C and G. Bishwanath (2004). Investment Climate and Total Factor Productivity in Manufacturing: Analysis of Indian States. Indian Council for Research on International Economic Relations Working Paper 127.

\footnotetext{
*Corresponding author.

E-mail address: ajagbefa@ funaab.edu.ng
} 